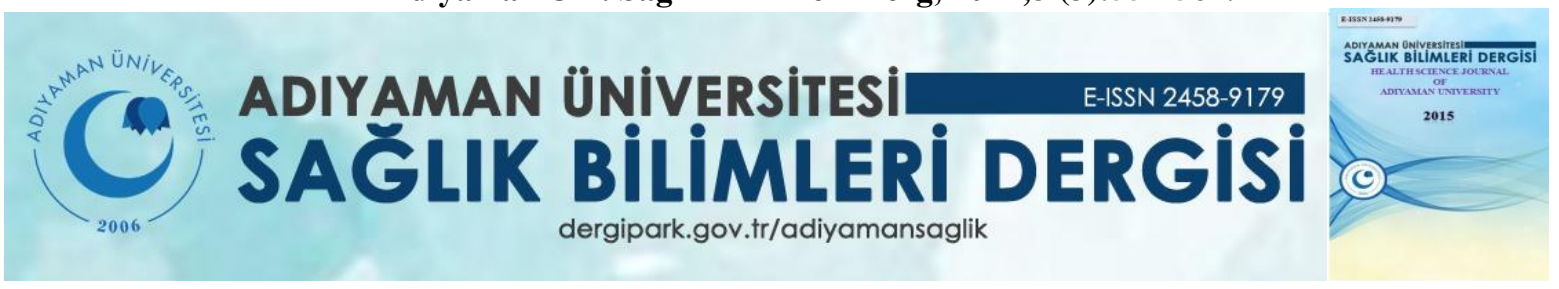

\title{
Araștırma/Research
}

\section{Bel ağrısı nedeniyle polikliniğimize başvuran hastalarda skolyoz sıklığı ve Cobb açısı değerlerinin yaş ve cinsiyet ile ilişkisi.}

\author{
Ayşe Atılgan ÇELIK ${ }^{1}$, Semra COŞKUN ${ }^{1}$, Onur KILINÇ ${ }^{1}$, Adem YILDIRIM ${ }^{1}$ \\ ${ }^{1}$ :Adiyaman Üniversitesi Tıp Fakültesi, Fiziksel Tıp ve Rehabilitasyon Anabilim Dalı, Adıyaman, Türkiye
}

\section{Özet}

Amaç: Bu çalışmanın amacı polikliniğimize bel ağrısı ile başvuran hastalarda skolyoz sıklığını saptamak ve Cobb açısı ile yaş ve cinsiyet arasında ilişkisi olup olmadığını araştırmaktı.

Yöntem: Bel ağrısı ile polikliniğimize başvuran 10837 hastanın verileri retrospektif olarak değerlendirildi. Öykü ve fizik muayane bulgularına göre skolyozdan şüphelenilip skolyoz grafisi çektirilen 130 hastanın verileri çalışmamıza dahil edildi. Hastaların omurga eğrilik dereceleri radyografik olarak anterio-posterior yönde tüm omurgayı görmeyi sağlayan skolyoz grafisi üzerinde Cobb açısı ölçümü yöntemi ile değerlendirildi. Cobb açısı 10 derece üzerinde olan hastalar skolyoz olarak değerlendirildi. Skolyoz sıklığı, Cobb açısı değerinin yaş ve cinsiyet ile olan ilişkisi araştırıldı.

Bulgular: Çalışmaya alınan 130 hastanın 80 tanesi kadın $(\% 61,5), 50$ tanesi ise erkek idi $(\% 38,5)$. Cinsiyete göre yaş ortalamaları arasında istatistiksel olarak anlamlı fark bulunamadı. 111 hastada $(\% 85,4)$ Cobb açısı $<10$ derece, skolyoz tanısı alan 19 hastada ise $(\% 14,6) \geq 10$ derece olarak ölçüldü. Skolyoz sıklığı binde 1,75 idi. Çalışmaya alınan kadın ve erkek hastaların Cobb açısı ortalamaları sırasıyla 5,81 $\pm 4,22$ ve 5,32 \pm 4,29 idi. Hastaların Cobb açısı ölçüm sonuçlarının cinsiyete göre dağılımına bakıldığında anlamlı fark olmadığı görüldü. Yaş ile Cobb açısı arasındaki ilişkisi incelendiğinde pozitif yönde zayıf bir korelasyon olduğu görüldü.

Sonuç: Bel ağrısıyla başvuran hastalarda skolyoz varlığı göz önünde bulundurulmalı, hastanın yaşı da göz önünde bulundurularak uygun radyolojik istemler yapılmalıdır.

Anahtar kelimeler: bel ağrısı; skolyoz; Cobb açısı

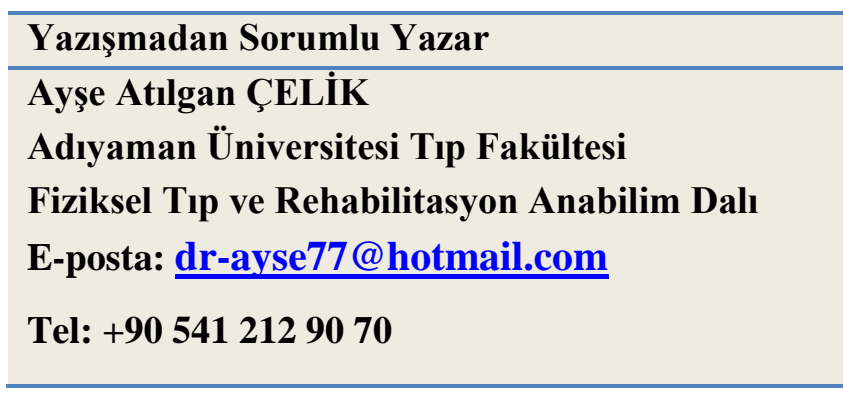

DOI:10.30569/adiyamansaglik.374982

\begin{tabular}{ll}
\hline Geliş Tarihi: & $\mathbf{0 4 . 0 1 . 2 0 1 8}$ \\
\hline Kabul Tarihi: & $\mathbf{0 9 . 0 1 . 2 0 1 8}$ \\
\hline
\end{tabular}


The frequency of scoliosis in patients with low back pain who admitted to our clinic and the relationship between Cobb angle, age and gender.

\section{Summary}

Aim: The aim of this study was to determine the frequency of scoliosis in patients who applied to our outpatient clinic with low-back pain and to investigate whether there is a relation between Cobb angle and age and gender.

Material and methods: The data of 10.837 patients who applied to our polyclinic with lowback pain were retrospectively evaluated. According to history and physical examination, 130 patients who were requested scoliosis radiography were included in the study. Patients' spine curvature degrees were assessed by Cobb's angle measurement method on a scoliosis radiography which allows the whole spine to be viewed radiographically in anterio-posterior direction. A scoliosis is defined as a lateral spinal curvature with a Cobb angle of $10^{\circ}$ or more. The frequency of scoliosis, the relationships between Cobb angle, age and gender were investigated.

Results: Of the 130 patients, 80 were female $(61.5 \%)$ and 50 were male $(38.5 \%)$. No statistically significant difference was found between the average values of ages according to gender. Cobb angle was $<10$ degrees in 111 patients $(85,4)$ and $\geq 10$ degrees in 19 patients diagnosed as scoliosis (14.6\%). The frequency of scoliosis was 1,75 per thousand. The mean Cobb angles of female and male patients were $5.81 \pm 4.22$ and $5.32 \pm 4.29$, respectively. There was no significant difference when the Cobb angle measurement results of the patients were analyzed according to the gender. When the relation between age and Cobb angle was examined, it was seen that there was a weak correlation in the positive direction.

Conclusion: The presence of scoliosis should be considered in patients presenting with low back pain. Appropriate radiological requests should be made considering the age of the patient.

Key words: low back pain; Scoliosis; Cobb's angle 


\section{Giriş}

Bel ağrısı, tüm toplumları etkileyen, yol açtığı fonksiyonel kısıtll1ıklar sonucu iş gücü kaybı ve ekonomik kayıplara yol açan yaygın bir sağlık problemi ve önemli bir halk sağlı̆̆ı sorunudur $(1,2)$. Kas iskelet sistemi ile ilgili branşlarda en stk poliklinik başvuru sebeplerinden biridir. Ülkemizde bel ağrısının yaşam boyu prevalansına baktığımızda kentsel bölgelerde $\% 50$, kırsalda ise $\% 80$ civarındadır (3). Kadınlarda daha sık görülmekte ve sıklı̆̆ yaşla birlikte artış göstermektedir $(4,5,6)$. Bu kadar yaygın görülen bir semptom olmasına rağmen hastaların $\% 85$ 'inde bel ağrısına neden olan patoloji net olarak saptanamamaktadır (1). Bel ağrısı \%97 oranında mekanik kaynaklıdır (1). Konjenital anomaliler (kifoz, skolyoz, transisyonel vertebra), idiopatik skolyoz, travmalar, lomber sprain/strain, dejeneratif faktörler, mekanik bel ağrısı sebeplerinden birkaçıdır (7). Mekanik olmayan bel ağrıları sebepleri ise: neoplazmlar, enfeksiyonlar, inflamatuar hastalıklar, metabolik kemik hastalıkları ve yansıyan ağrılardır $(4,5,6)$. Bel ağrısı sadece erişkin grupta değil, aynı zamanda çocukluk ve ergenlik döneminde de görülebilen bir rahatsızlıktır. Çocuklarda ve ergenlerde görülme sıklığı \%12-33 olarak bildirilmiştir. Japonyada yapılan bir çalışmada okul taramasında erkek çocukların \%52,3' ünde, kız çocukların ise \%47,7'sinde bel ağrısı bulunmuştur (8).

Skolyoz, omurganın koronal planda laterale deviasyonu, sagittal planda hipokifoz, lordoz, aksiyal planda ise rotasyonu ile karakterize postural bir bozukluğu, 3 boyutlu bir deformitesidir (9). Radyolojik olarak ise omurganın laterale olan 10 derece üzerindeki eğriliğidir. Her ne kadar skolyozda ağrı tartışmalı bir konu olsa da erişkin skolyozunda ağrı özellikle de kronik bel ağrısı normalden 3 kat daha sıktır (10). Genel olarak bakıldığında skolyozda eğriliğin derecesi arttıkça omurga normal yük dağılımını sağlayamamakta ve bel ve sırt ağrıları gelişebilmektedir. Skolyoz bel ağrısının bir nedeni olarak kabul edilse de gerçekte bel ağrısı ile doktora başvuran hastalardaki sıklığı ve önemi halen araştııılmaya muhtaçtır. 
$\mathrm{Bu}$ çalışmanın amacı polikliniğimize bel ağrısı ile başvuran hastalarda skolyoz sıklığını saptamak ve bel ağrısı ile yaş ve cinsiyet arasında ilişkisi olup olmadığını araştırmaktı.

\section{Gereç ve Yöntemler}

Çalışmada Ocak 2016 - Kasım 2017 tarihleri arasında bel ağrısı ile polikliniğimize başvuran 10.837 hastanın verileri retrospektif olarak değerlendirildi. Bu hastalardan skolyoz grafisi çekilen 130 hastanın verileri çalışmamıza dahil edildi. Hastaların demografik verileri (yaş, cinsiyet vb.) ve ek hastalıkları kaydedildi. Skolyoz grafisi çekilmekle birlikte lomber disk hernisi, enflamatuar bel ağrısı, spondilolistezis tanısı almış hastalar çalışmamıza dahil edilmedi. Hastaların omurga eğrilik dereceleri radyografik olarak anterio-posterior yönde tüm omurgayı görmeyi sağlayan skolyoz grafisi üzerinde Cobb açısı ölçümü yöntemi ile değerlendirildi. Ölçüm sonuçları kaydedildi.

\section{Cobb Yöntemi ile Omurga Ĕgrilik Derecesinin Ölçülmesi}

Eğriliğin konkav tarafında intervertebral aralıklar daha dardır. İntervertebral aralıkların genişlemeye başladığı seviyeler uç omurgalardır (end vertebra). Üst uç vertebranın üst kenarı ve alt uçtaki vertebranın alt kenarına paralel olarak uzatılan çizgiler arasındaki açı Cobb açısıdır. Bu açı çok zaman radyografi dışında kaldığından, pratikte yukarıdaki çizgilerden uzatılan dikmeler arasındaki “a” açısı kullanılır (11). Cobb açısı ölçüm yöntemi Şekil 1'de gösterilmiştir. 


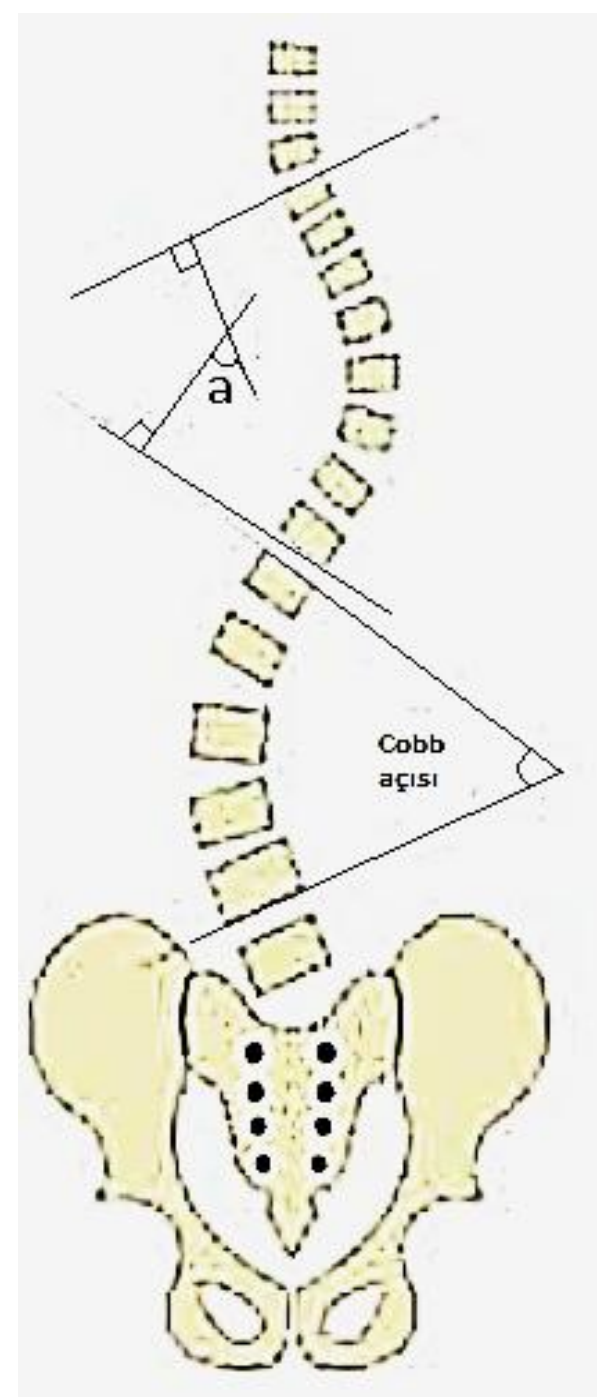

Şekil 1: Cobb açısı ölçüm yöntemi

\section{Istatistiksel Analiz}

İstatistiksel analizlerde Windows için SPSS (ver. 18, SPSS Inc, Chicago Ill, USA) istatistik programı kullanıldı. Kategorik değişkenler yüzde olarak, sürekli değişkenler ortalama \pm standart sapma (minimum-maksimum) olarak gösterildi. Kadın ve erkeklerin yaş ve Cobb açısı ölçüm ortalamaları bağımsız değişkenler t testi ile karşılaştırıldı. Yaş ile Cobb açısı ölçüm sonuçları arasındaki potansiyel ilişkinin varlığı ve yönünü değerlendirmek için korelasyon testleri yapıldı. Tüm istatistiksel analizlerde anlamlılık düzeyi $\mathrm{p}<0.05$ olarak kabul edildi. 


\section{Bulgular}

İki yıllık süre içerisinde bel ağrısı ile polikliniklerimize başvuran 10.837 hastadan 130 tanesinde $(\%$ 0,012) skolyoz grafisi çekildiği görüldü. Çalışmaya alınan bu 130 hastanın 80 tanesi kadın $(\% 61,5), 50$ tanesi ise erkek idi $(\% 38,5)$. Kadınların yaş ortalaması 21,35 $\pm 7,92$ (9-42), erkeklerin yaş ortalması ise $21,10 \pm 7,55$ (7-52) idi. Cinsiyete göre yaş ortalamaları arasında istatistiksel olarak anlamlı fark bulunamadı $(\mathrm{p}=0,589)$. Hastaların demografik verileri Tablo 1'de gösterilmiştir.

Tablo 1: Hastaların demografik verileri

\begin{tabular}{|c|c|c|c|c|c|c|}
\hline \multirow{5}{*}{ 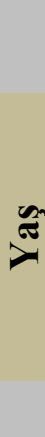 } & & Sayı (N) & Ortalama & Standart Sapma & Minimum & Maksimum \\
\hline & Kadın & 80 & 21,35 & 7,92 & 9 & 42 \\
\hline & Erkek & 50 & 21,10 & 7,55 & 7 & 52 \\
\hline & Toplam & 130 & 21,25 & 7,75 & 7 & 52 \\
\hline & $p^{*}$ & & 0,859 & & & \\
\hline
\end{tabular}

*:Bağımsız değişkenler t testi ile kadın-erkek yaş ortalamasının karşılaştırılması

Çalışmaya alınan 80 kadın hastanın Cobb açısı ortalaması 5,81 $\pm 4,22 ; 50$ erkek hastanın ise Cobb açı ortalaması 5,32 \pm 4,29 idi. Tüm hastaların Cobb açısı ortalaması ise 5,62 \pm 4,31 idi. Hastaların Cobb açı ölçüm sonuçlarının cinsiyete göre dağılımına bakıldığında anlamlı fark olmadığı görüldü $(\mathrm{p}=0,529)$. Hastaların Cobb Açı ölçüm sonuçlarının cinsiyete göre dağılımı Tablo 2'de gösterilmiştir. 
Tablo 2: Hastaların Cobb Açısı ölçüm sonuçlarının cinsiyete göre dağılımı

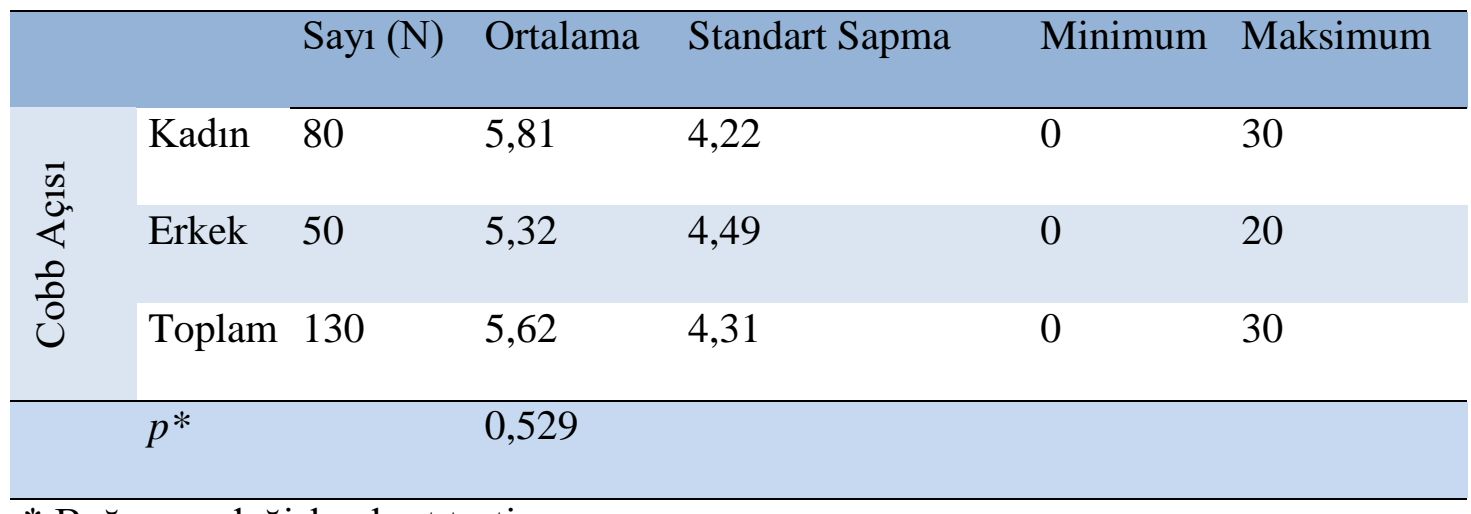

*:Bağımsız değişkenler t testi

Yüz otuz hasta Cobb açısı sonuçlarına göre gruplandırıldığında 19 hastada $(\% 14,6)$ Cobb açısı $\geq 10$ (ortalama: 13,05 \pm 5,16) derece olarak ölçüldü (skolyoz tanısı alan grup). 111 hastada $(\% 85,4)$ ise Cobb açısı $<10$ derece idi (ortalama: 4,35 $\pm 2,51)$. Skolyoz tanısı almayan bu 111 hastanın 10 tanesinde (\% 7,7) Cobb açısı 0 derece ve 101 tanesinde $(\% 77,7)$ Cobb açısı 0-10 derece olduğu görüldü. Bel ağrısı ile başvuran tüm hastalar göz önünde bulundurulduğunda Skolyoz sıklığı (19/10.837) binde 1,75 idi. Skolyozu olmayan ve olan hastaların Cobb Açısı ölçüm sonuçlarına göre gruplama Tablo 3'te gösterilmiştir.

Tablo 3: Cobb Açısı ölçüm sonuçlarına göre gruplama

\begin{tabular}{c|cccccc}
\hline & $\begin{array}{c}\text { Say1 } \\
(\mathrm{N})\end{array}$ & Ortalama & Standart Sapma & Minimum & Maksimum \\
\cline { 2 - 6 }$\geq 10$ derece (Skolyoz) & 19 & 13,05 & 5,16 & 10 & 30 \\
\hline 10 derece & 111 & 4,35 & 2,51 & 0 & 9 \\
$0-10$ derece & 101 & 4,78 & 2,2 & 1 & 9 \\
$\quad 0$ derece & 10 & 0 & 0 & 0 & 0 \\
\hline
\end{tabular}

Yaş ile Cobb açısı arasındaki ilişkisi incelendiğinde pozitif yönde zayıf bir korelasyon olduğu görüldü $(r=0,243, p=0,005)$. Yaş ile Cobb Açısı ölçüm sonuçlarının korelasyon analizi sonucu Tablo 4'te verilmiştir. Hastalarının yaşları ile skolyoz derecelerinin dağılımı ve ilişkinin 
yönünü gösteren eğri şekil 2'de; Cobb açısı değerine göre ortalama yaş ve cinsiyet dağılımı ise Şekil 3'te gösterilmiştir.

Tablo 4: Yaş ile Cobb Açısı ölçüm sonuçlarının korelasyon analizi

\begin{tabular}{lll}
\hline & Cobb Açısı & $p^{*}$ \\
Yaş & $\mathrm{r}$ & $\mathbf{0 , 0 0 5}$
\end{tabular}

*:Pearson korelasyon analizi

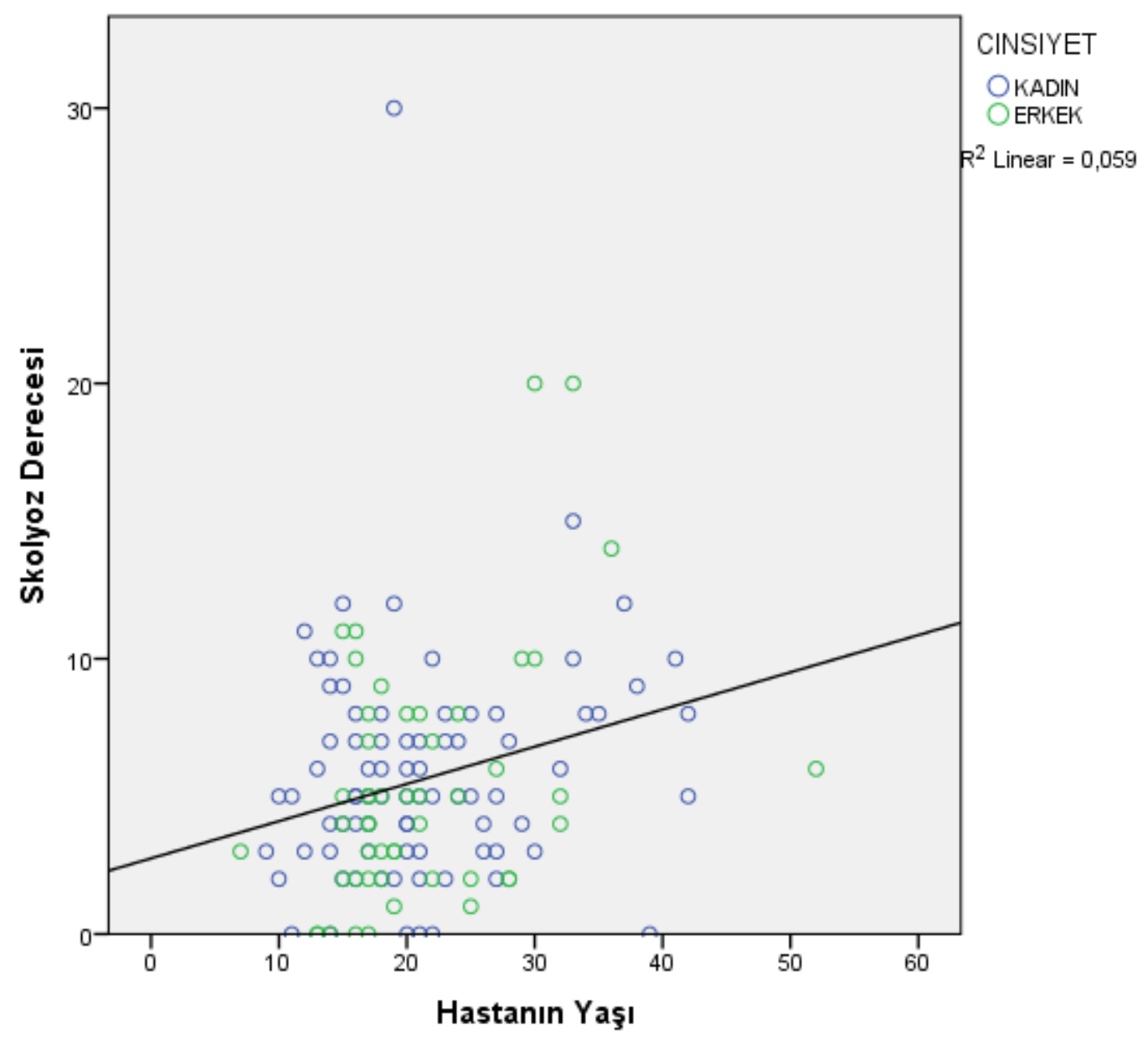

Şekil 2: Hasta yaşı ile skolyoz derecesi arasındaki ilişki. 


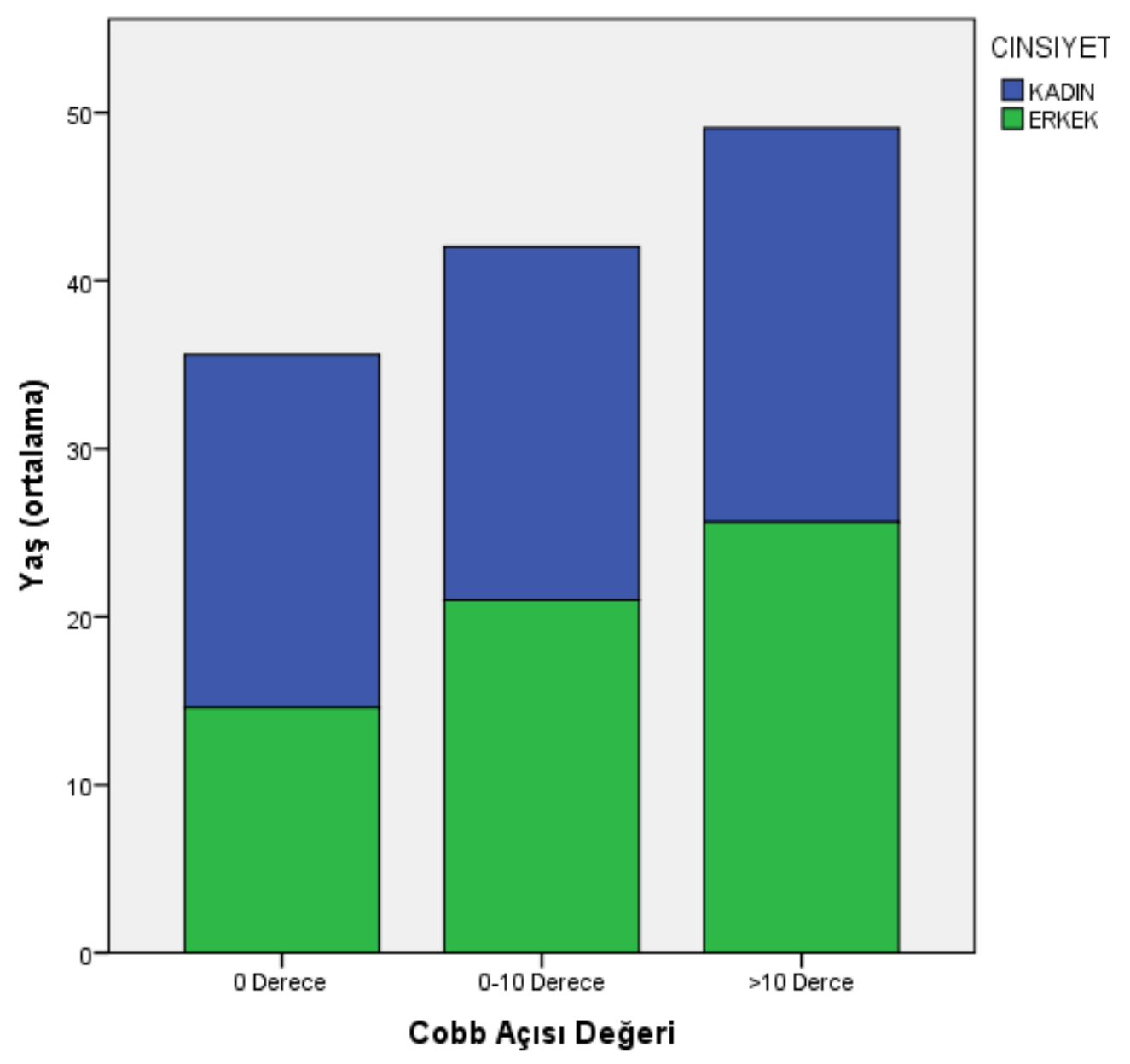

Şekil 3: Cobb açısı değeri ile ortalama yaş değerlerinin cinsiyete göre dağılımı.

\section{Tartışma}

Skolyoz, omurganın koronal planda sağa veya sola 10 derece üzerindeki lateral eğriliği olarak tanımlanır fakat eğrilik sadece omurgada sınırlı kalmaz omuz kuşağı, pelvisi de etkileyerek üç boyutlu bir deformiteye yol açar (12). Skolyoz nedenleri ise \%70-90 idiyopatiktir (4,5,6). Diğer nedenler arasında nörolojik, travma, eklem ve bağ dokusu hastalıkları sayılabilir (12). Amerikan skolyoz Araştırma Cemiyetine göre skolyoz yapısal ve yapısal olmayan olarak ikiye ayrılmaktadır. Tüm skolyozların \%70 ini yapısal grupta yer alan idiyopatik grup oluşturur. İdiyopatik grupta ise en sık görülen adölesan idiyopatik skolyozdur (9). Skolyoz prevalansı okul çocuklarında \%1-2, 25 yaş ve üzeri erişkinlerde $\% 8$ 'dir. Yılmaz 
ve ark. yaptıkları çalışmalarında Çanakkale'de 7-14 yaş grubunda skolyoz prevalansını $\% 0.31$ ve kız/erkek oranını 3/1 olarak bildirmişlerdir (6).

Skolyozda bozuk postür omurgada denge bozukluğuna, yorgunluğa ve sonuçta nosiseptif uyarılarla ağrıya yol açar. Bozuk postürü düzeltmek için kaslar aşırı gerilirler ve zamanla kaslarda spazm ve ağrı ortaya çıkar $(13,14)$. Skolyotik eğriliğin konveks tarafındaki kaslar aşırı gerilir ve ligamanları zorlar, konkav tarafta ise kaslarda güçsüzlük ve kısalmalar oluşur (9). Skolyoz sonucu hastaların postürü bozulur, bozuk postüre bağlı omurga biyomekaniği etkilenir, kullanmama atrofileri gelişir ve bu da omurgada asimetrik yüklenmelere sebep olur (15-16). Bir taraf kaslar aşırı yüklenmeye bağlı kontrakte olur, diğer tarafta ise bazı kaslar atrofiye uğrar ve hastalarda mekanik tipte ağrı olur. Ağriya bağlı bel bölgesindeki paraspinal kasların bir kısmı zayıflar, bu da mevcut ağrıda artışa yol açar. Ağrısı olan hastaların egzersiz toleransının düşmesi ve egzersiz yapmaktan kaçınmaları sonucu kaslar daha fazla atrofiye uğrar ve bir kısır döngü oluşur (17).

İdiyopatik skolyozlu hastaların önemli bir kısmı ağrıdan yakınmazlar ve muayenede nörolojik bulguya da rastlanmaz. Diğer taraftan yeterli hamstring esnekliği, yeterli karın ve sırt kas kuvvetine sahip olmayan bazı gençler bel ağrısından yakınabilir $(4,5,6)$. Her ne kadar skolyozda ağrı tartışmalı bir konu olsa da erişkin skolyozunda ağrı özellikle de kronik bel ağrısı normalden 3 kat daha sıktır (10). Skolyozu olan adölesan grupta bel ağrısı prevalansı \%24-36 olarak bildirilmiştir (18). Diğer taraftan özellikle pediatrik grupta skolyozun tek başına bel ağnısı nedeni olmadığını ancak yüksek derecede skolyozu olan çocuklarda ağrının görüldüğünü savunanlar da mevcuttur. Bel ağrısından yakınan skolyozlu çocukların üçte birinde syringomyeli, tethered cord, tümörler, neurofibromatozis gibi eşlik eden ikincil bir ağrı yapıcı neden olabileceği akılda tutulmalıdır $(19,20)$. Skolyozu olan çocuklarda bel ağrısı sıklığını araştıran çalışmalarda çeşitli sonuçlar bildirilmiştir. Japonyada yapılan bir başka 
çalışmada ise skolyoz tespit edilen çocukların \%27,5 'inde bel ağrısı olduğu bildirilmiştir (8). Demir ve ark.'ın ilkokul çocuklarında yaptıkları bir tarama çalışmasında ise omurgada postüral asimetrisi olan çocukların \%4,3'ünde bel-kalça ağrısı olduğu kaydedilmiştir (21). Literatürdeki çalışmalar ve verilen oranlar özellikle skolyozu olan pediatrik gruptaki hastalarda bel ağrısı sıklığına yoğunlaşırken tüm yaş gruplarını içeren ve bel ağrısı olan hastalardaki skolyozun varlığ 1 veya sıklığına ait veriler içermemektedir. Literatürden farklı olarak bu çalışmada bel ağrısı nedeniyle tetkik edilen hastalardaki skolyoz sıklığı araştırılmış ve bel ağrısı olan 10.837 hastanın 19 tanesinde (binde 1,75 oranında) skolyoz varlığ saptanmıştır. Çalışmalarda genel skolyoz prevalansı genetik özellikler, taranan yaş aralığı, kabul edilen skolyoz açısı ve çalışmayı tamamlayan olgu sayısı gibi parametrelere bağlı olarak \%0,13 - 13,6 arasında farklılık göstermektedir $(5,6)$. Bizim çalışmamızdaki düşük oranının temel sebebinin tüm hastalardan skolyoz grafisinin istenmemiş olması ve çalışma sonuçlarının sadece skolyoz grafisi istenmiş hastaları içermesi olduğunu düşünüyoruz. $\mathrm{Bu}$ durumda skolyozu olan çok sayıda bel ağrılı hastanın uygun klinik ve radyografik inceleme yapılmadığı için atlandığı açıktır.

Cinsiyete göre, bel ağrısı sıłlığını inceleyen çalışmalarda çelişkili sonuçlar bildirilmiştir. Kadınlarda daha sık görüldüğünü bildiren çalışmalarda yaşam boyu bel ağrısı prevalansını Shehab ve ark. (22) kadınlarda \%64,7, erkeklerde ise \%50,8 olarak bildirirken; Kovacs ve ark. (23) kadınlarda \%69,3, erkeklerde ise \%50,9 olarak bildirmişlerdir. Bu çalışmaların aksine Newcomer ve ark. (24) erkeklerde \%57 ve kadınlarda \%44 oranlarını bildirmiştir. Bu konuda yapılan bir meta-analizde de (25) cinsiyet ve yaşam boyu bel ağrısı yaygınlığı arasında istatistiksel olarak anlamlı fark olmadığg bildirilmiştir. Literatüre benzer şekilde bizim çalışmamızda da cinsiyet ile bel ağrısı oranları ve Cobb açısı değerleri arasında anlamlı fark olmadığ 1 görüldü. 
Yaş ile skolyoz açısı arasındaki ilişkiye değinecek olursak, daha önceleri genel görüş, idiyopatik skolyozun iskelet maturasyonundan sonra ilerlemediği yönünde iken tedavi edilmeyen birçok skolyoz vakasının iliyak krest füzyonunun tamamlanmasından sonra ilerlemeye devam ettiği ve yetişkinlerde skolyozun sıklıkla ilerlediği gözlenmiştir. Bir çalışmada tedavi edilmeyen idiyopatik skolyozlu olgularda 16-20 yaş arasındaki olguların yaklaşık \%80'inde, 20 yaşından büyük hastaların ise \%60'ında skolyozda ilerleme olduğu bildirilmiştir (26). Bizim çalışmamızda da literatürle uyumlu olarak yaş ile skolyoz açısının zayıf ta olsa pozitif yönde korele olduğu gösterilmiştir.

Retrospektif bir çalışma olması nedeniyle hastaların klinik bulgularına (detaylı bel muayenesi verileri, bel ağrısının yayılımı, şiddeti, ek nörolojik bulguların varlı̆ğ vb.) yer verilememiş olması yanında bel ağrısının takip verilerini de içermemesi çalışmamızın en önemli kısıtlılıklarını oluşturmaktadır.

\section{Sonuç}

Bel ağrısıyla fizik tedavi polikliniklerine başvuran hastalarda skolyoz varlığı göz önünde bulundurulmalı, hastanın yaşı da göz önünde bulundurularak uygun radyolojik istemler yapılmalıdir. 


\section{Kaynaklar}

1. Seçer M, Muradov JM, Dalgııç A. Evaluation of congenital lumbosacral malformations and neurological findings in patients with low back pain. Turkish Neurosurgery 2009;19(2):145-148.

2. Takmaz SA. Kronik bel boyun ağrll hastaya yaklaşım ve değerlendirme yöntemleri. TOTBİD Dergisi 2017;16:81-88.

3. Nabiyev V, Ayhan S, Acaroğlu E. Bel ağrısında tanı ve tedavi algoritması- TOTBİD Dergisi 2015;14:242-251.

4. Kavak C. Adölesan idiyopatik skolyozun cerrahi tedavisinde anterior ve posterior enstrümentasyon sonuçlarının karşılaştırılması (Uzmanlık tezi). 2005 Adana, Çukurova Üniversitesi Tıp Fakültesi.

5. Trobisch P, Suess O, Schwab F. Idiopathic scoliosis. Deutsches Ärzteblatt International 2010;107(49):875884.

6. Yılmaz H, Zateri C, Vurur s, Bakar C Prevalence of adolescent idiopathic scoliosis among primary school children in Canakkale, Turkey. Scoliosis 2012;7(1):37.

7. Yıldırım A. Kronik Diskojenik Bel Ağrıları ve Cerrahi Dışı Tedavi Yöntemleri: Güncelleme. Dicle Medical Journal 2016;43(1):181-191.

8. Sato T, Ito T, Hirano T, Morita O, Kikuchi R, Endo N, Tanabe N. Low back pain in childhood and adolescence: assessment of sports activities. European Spine Journal 2011;20(1):94-99.

9. Erdal A. Skolyoz ve Rehabilitasyonu. Editör: Göksoy T, Şenel K. Ortopedik Rehabilitasyon, 2. Baskı, Bilimsel Medikal Yayınc1lı, İstanbul, 2016:283-292.

10. Weinstein SL, Dolan LA, Spratt KF, Peterson KK, Spoonamore MJ, Ponseti IV. Health and function of patients with untreated idiopathic scoliosis: a 50-year natural history study. Jama 2003;289(5):559-567.

11. Oğuz E, Ekinci Ş, Erşen Ö. Ergen İdiyopatik Skolyozda Radyolojik Değerlendirme ve Sınıflama Sistemlerinin İncelenmesi. TOTBİD dergisi 2013;12(1):73-82.

12. Yılmaz HG -İdiyopatik Skolyozda Egzersiz Reçeteleme. Türkiye Fiziksel Tıp ve Rehabilitasyon Dergisi 2014;60(2):31-35.

13. Griegel-Morris P, Larson K, Mueller-Klaus K, Oatis CA. Incidence of common postural abnormalities in the cervical, shoulder, and thoracic regions and their association with pain in two age groups of healthy subjects. Physical therapy 1992;72(6):425-431.

14. Ünlü Z, Yorgancıoğlu R. Sırt-boyun-omuz bölgesinde ağrı olan kişilerde postür analizi. Romatoloji Tıbbi Rehabilitasyon Dergisi 1993;4:166-169.

15. Bilgin S. Multifitus Kası ve Klinik Etkisi. Journal of Exercıse Therapy And Rehabilitation Erişim: http://www.jetr.org.tr/wp-content/uploads/klinik-not-sevil-bilgin-haziran-2015.pdf. 
16. Bilgiç S, Erşen, Ö. (). Adolesan İdiyopatik Skolyoz Konservatif Tedavisi. Turkiye Klinikleri Journal of Orthopaedics and Traumatology Special Topics 2017;10(2):118-123.

17. Oskay D, Yakut Y. Bel Ağrısı Olan ve Olmayan Kadınların Fiziksel Uygunluk Parametrelerinin Karşılaştırılması. Göztepe Tip Dergisi 2011;26(3):117-122.

18. Balıkçı T, Bezer M. Çocuklarda bel ağrısı. TOTBID Dergisi 2015;14:262-270.

19. Önal VS, Gemalmaz HC. Çocuk ve Adolesan Yaş Grubunda Bel Ağrıları; Yaklaşım, Tanı ve Tedavi. Acıbadem Üniversitesi Sağlık Bilimleri Dergisi 2014;5(1):20-23.

20. Herring JA, Tachdjian's Pediatric Orthopaedics: Back pain. Third edition, Philadelphia, WB Saunders Comp, 2002:95-107.

21. Demir YP, Çırak Y, Dalkılınç M, Yılmaz GD, Uraş İ, Kömürcü M. İlkokul Çocuklarında Çanta Taşıma, Bilgisayar Kullanma Alışkanlığı ve Postür. Ankara Medical Journal 2012;12(4):182-187.

22. Shehab D, Al-Jarallah K, Al-Ghareeb F, Sanaseeri S, Al-Fadhli M, Habeeb S: Is low-back pain prevalent among Kuwaiti children and adolescents? A governorate-based study. Medical Principles and Practice 2004;13:142-146.

23. Kovacs FM, Gestoso M, del Real MT G, López J, Mufraggi N, Méndez JI. Risk factors for non-specific low back pain in school children and their parents: a population based study. Pain 2003;103:259-268.

24. Newcomer K, Sinaki M. Low back pain and its relationship to back strength and physical activity in children. Acta Paediatrica 1996;85(12):1433-1439.

25. Calvo-Muñoz I, Gómez-Conesa A, \& Sánchez-Meca J. Prevalence of low back pain in children and adolescents: a meta-analysis. BMC pediatrics 2013;13(1):14.

26. Bjerkreim I, Hassan I. Progression in untreated idiopathic scoliosis after end of growth. Acta Orthopaedica Scandinavica 1982;53(6):897-900. 